\title{
The Consequences of Public Procurement and Its Associated Irregularities in Ghana
}

\author{
Emmanuel Abeku ESSEL ${ }^{10}$
}

\begin{abstract}
Ghana spends a large number of its public resources on the acquisition of goods, works and services with most of them being sourced through Public Procurement. The country in its quest to ensure transparency and efficiency in its public transaction established the Public Procurement Authority (PPA) and clothed it with powers by an Act of Parliament to discharge the given responsibilities. However, since 2003 when the $4^{\text {th }}$ Republican rule was instituted, not a single government regime has exited from office without recourse to irregularities associated with the procurement processes as reported by the Auditor General's Annual Reports or reports by Civil Society Organisations (CSOs). The goal of this paper is to look at the consequences of these irregularities in the procurement process posed to Ghana's development. The methodology used in carrying out this study centred mainly on secondary data, and some recommendations have been offered for consideration.
\end{abstract}

Keywords: procurement, irregularities, consequences, government, corruption

\section{Introduction}

Fighting corruption is not easy in a third world country like Ghana. Many Sub-Saharan African countries are battling corruption every day with the hope of winning them. Unlike many criminals, dishonest public officials often continue to have power and influence. Political interference, even in cases involving low-level officials, can frequently derail a prosecution. Civil society organisations may help uncover fraudulent activities, but they also may undermine effective prosecution by inadvertently tampering with evidence or tipping off the crooked politicians. As a consequence, a heightened sense of accountability among politicians, public bodies and institutions has emerged, as has a consequent demand for anticorruption agencies. Given the widespread perception of corrupt practices and inefficiencies in the process, the Government and its development partners thus, found it expedient to take the necessary steps to revamp the process and also build trust to eliminate corruption. It is in light of these that the Public Procurement Act, Act 663 was passed in 2003. This law, which is a comprehensive legislation designed to eliminate the shortcomings and organisational weaknesses which were inherent in public procurement

PhD student, University of Public Service; e-mail: abeabi@yahoo.com 
in Ghana, sought to ensure sanity and value for money in the public procurement landscape. Ghana spends a significant portion of its public resources on the acquisition of goods, works and services and these are sourced through the Public Procurement Authority (PPA). This mechanism was a way of ensuring efficiency and transparency, because about 80 per cent of the country's national tax revenue, which is an equivalent of about 17 per cent of the country's GDP, is spent through public procurement. ${ }^{2}$

According to Ofori-Mensah and Rutherford (2011), ${ }^{3}$ most audit reports on public procurement in Ghana have, in most cases, highlighted several procurement breaches. For instance, the immediate past Chairperson of the Electoral Commission (EC) of Ghana was deemed to have blatantly breached procurement laws in the award of several contracts in her three-year period at the helm of affairs, prior to the 2016 elections. The breaches upon which she was removed from office included but was not limited to the creation of a new EC logo; engagement of lawyers without going through the proper procurement process as no formal contractual arrangement between the EC and the law firm (Sory@Law); unilaterally abrogating a duly procured contract with a tech company, STL; the decision to acquire a new office block for the Commission; the award of a contract for the construction of pre-fabricated District Offices for the Commission, and a contract for consultancy for the pre-fabricated works. Ofori-Mensah and Rutherford (2011) further added in their study that, the goal for the enactment of the Public Procurement Law, 2003 (Act 663) which was to eliminate the shortcomings and organisational weaknesses that were inherent in the public procurement process in Ghana was far from being achieved. In the face of these challenges, it became evidently clear that, the best way to ensure an efficient public procurement system and to have value for money in the area of government expenditure, which is essential to a country facing enormous developmental challenges is through the proper procurement process.

The World Bank ${ }^{4}$ reported that about 50-70 per cent of the national budget of Ghana (after personal payments), is procurement-related. The passage of the law on Procurement undeniably set into motion other relevant governing and regulatory mechanisms and ultimately, the Public Procurement Authority. All this was an effort to regulate government expenditure in the area of Procurement, something, which came into being after the Public Financial Management Reform Programme (PUFMARP) in 1996 with the hope that it would help end the perennial problem of government resources going down the drain in the area of Procurement. ${ }^{5}$ Ever since the law was passed with the belief that it would help push back all manner of irregularities and leakages in governmental expenditure on Procurement, the anomalies still persist. Considering the significant proportion of national revenue used on Procurement, it could be said that most governments around the

2 Collins Ameyaw, Sarfo Mensah and Ernest Osei-Tutu, 'Public Procurement in Ghana: The Implementation Challenges to the Public Procurement Law 2003 (Act 663)', International Journal of Construction Supply Chain Management 2, no 2 (2012), 55-65.

3 Michael Ofori-Mensah and Lucas Rutherford, 'Effective Parliamentary Oversight: Mission Impossible?', Governance Newsletter 17, no 3 (2011), 1-9.

4 The World Bank, Public Procurement Act of Ghana - Country procurement assessment report (Washington, D.C.: The World Bank, Report No. 29055, 2003).

5 Ameyaw et al., 'Public Procurement in Ghana'. 
world often flop in their meticulousness in the area of contracts or procurement process, and this leads to inefficiencies in the country's governance system. This practice leaves in its trails harsh environmental conditions for the citizenry, social and economic impacts. ${ }^{6}$ These irregularities ultimately culminate into the loss of huge sums of money, something that has a far-reaching consequence on the country and the citizenry, which invariably impedes national development.

As stated by Hui et al (2011), ${ }^{7}$ corruption could threaten legitimacy in governance, and as such, good policies and procedures must be put in place, if not to check it, but to eliminate corruption in order to enhance transparency, accountability and integrity. Public procurement irregularities undeniably are a risky phenomenon which if not well checked can serve as an avenue for embezzlement and misappropriation of state funds. In recent times, however, there have been calls to consider long-term economic, social and environmental benefits of governments' procurement practices towards continuous development. $^{8}$

The paper looked at the procurement processes in Ghana with emphasis on the irregularities that has engulfed the system and the consequences it has brought on the governance system in the country.

\section{Public procurement practices in Ghana}

Procurement is considered part of the budget and financial management in the national economy. Improvement in the public procurement system, therefore, has a direct and beneficial effect on the overall economic performance of the economy of every country.

In the words of Adu Sarfo and Baah-Mintah (2013) ${ }^{9}$ as cited by Tweneboah Senzu and Ndebugri (2017), ${ }^{10}$ financial management, mainly public financial management is an attempt made by the Government to ensure that reliably, the budget is either balanced or there is a surplus to deal with other contingencies. According to Lysons and Farrington (2012), ${ }^{11}$ the word procurement defies a single lexicon - in terms of definition. Neupane et al. (2014), ${ }^{12}$ referred to public procurement as processes through which government

6 Peter Adjei-Bamfo, 'Mainstreaming Sustainable Public Procurement in Ghana's Public Sector: The Role of E-Government’, 2017.

7 Wee Shu Hui, Radiah Othman, Normah Hj Omar, Rashidah Abdul Rahman and Nurul Husna Haron, 'Procurement issues in Malaysia', International Journal of Public Sector Management 24, no 6 (2011), 567593.

8 Stephen Brammer and Helen Walker, 'Sustainable Procurement in the public sector: an international comparative study’, International Journal of Operations \& Production Management 31, no 4 (2011), $452-$ 476.

$9 \quad$ Patrick Adu Sarfo and Richard Baah-Mintah, 'Assessing the Effect of the Procurement Act (663) on the Public Financial Management in Ashanti Region’, American Journal of Rural Development 1, no 4 (2013), 91-98.

10 Emmanuel Tweneboah Senzu and Huruna Ndebugri, 'Evaluating the Effectiveness of the Procurement Acts in Public Financial Administration; The Case Study in Ghana’, 2017.

11 Kenneth Lysons and Brian Farrington, Procurement and Supply Chain Management (Edinburgh Gate: Pearson Education Limited, 2012).

12 Arjun Neupane, Jeffrey Soar and Kishor Vaidya, 'An Empirical Evaluation of the Potential of Public E-Procurement to Reduce Corruption', Australasian Journal of Information Systems 18, no 2 (2014). 
agencies, departments and other public organisation acquire goods, services, works and activities from third parties. This includes renting, leasing, buying or purchasing supplies, construction, or services. The term also comprises all such functions (description of the requirement, selection and award of contracts, among others) that relates to obtaining goods and services by the Government to serve its citizens. Nichols (2002) ${ }^{13}$ observed that Procurement is an essential policy in the procurement process with the function of contributing to the achievement of government operations and improved service delivery. Hence, one can deduce from the words of Nichols (2002) that, the goal of Procurement is to ensure that government activities are carried efficiently.

As a way of regulating its procurement activities, Ghana has had a checked history in the area of several laws on the phenomenon called procurement. In 1960, the Government enacted the Contracts Act, 1960 (Act 25), and the Ghana Supply Commission Act which was revised and replaced in 1990 by the Provisional National Defence Council (PNDC) law 245. In 1976, the Ghana National Procurement Agency Decree, 1976 (SMCD 55) was also passed by the Supreme Military Council. In 1979, another law which also seeks to regulate government expenditure, the Financial Administration Decree (SMCD 221) was also passed. All these decrees, rules and instruments were meant to provide a comprehensive framework of administrative powers to regulate the activities of Procurement within the public sector. However, consecutive evaluation of the public procurement administrations in Ghana revealed substantial inefficiencies, corruption and lack of transparency in the procurement processes by governmental agencies because of an unclear legal framework, lack of harmonised procedures, regulations, vague official and administrative procedures needed in the management of the public procurement process. It also lacked capacity development of procurement practitioners and career paths for those in the Public and Civil Service entrusted with procurement powers.

This simple task of getting things supplied to governmental agencies to have the government machinery run smoothly in Ghana, however, has become a milking cow owing to some loopholes inherent in the Procurement Act. Taking a close look the Act, one can say specific rules emanate from it which according to Adu Sarfo (2011) ${ }^{14}$ must be adhered to, and failure to do so amounts to irregularities in the procurement process. Ghana, it is said remains one of the most corrupt nations in the world in reference to the annual Corruption Perceptions Index (CPI) released by Transparency International. In its 2019 report, Ghana placed $80^{\text {th }}$ out of 180 countries with an average score of 40 over $100 . .^{15}$

Tabish and Jha (2011) ${ }^{16}$ put public procurement irregularities into five categories, namely anomalies related to transparency; professional standards; fairness; contract monitoring and regulations; and procedures. However, one cannot lay claim and boldly

13 Philip M Nichols, 'Regulating Transnational Bribery in Times of Globalisation and Fragmentation', The Yale Journal of International Law 24, no 1 (1999), 257-304.

14 Patrick Adu Sarfo, Assessing the Effects of the Procurement Act (663) on Public Financial Management in Ashanti Region (Unpublished thesis submitted to the School of Graduate Studies, Kwame Nkrumah University of Science and Technology, Ghana, 2011).

15 Transparency International, ‘Corruption Perceptions Index 2019: Overview of Corruption and Anti-Corruption in Ghana', 2019.

16 Syed Zafar Shahid Tabish and K N Jha, 'Lesson learned from irregularities committed in public procurement', 2011. 
say that the passage of the Public Procurement Law and its implementation has made or brought about any significant effect in limiting corruption in the public procurement space in Ghana.

Schiele and McCue (2006) ${ }^{17}$ were also of the opinion that public procurement implementation challenges are affected in several ways environmentally. These factors, among other things, include market conditions, organisational and socio-economic environment and legal and political environment factors. Despite the numerous lapses found in the procurement process one can say that, regardless of the effort by the central Government and its related agencies to nib in the bud of the challenges facing the implementation of the regulations in the process and an understanding of adding value to the procurement procedure and also improve the capacity of procurement departments, a large number of governmental agencies act on their own and frequently by-pass the procurement regulations and do things on their own, something which feeds into the irregularities theory of the Procurement process in the country. Among other things, the public Procurement Act (663) regulates and defines the rules for public Procurement in Ghana. The preamble to the Act stipulates 'an act to provide for public procurement, establish the Public Procurement Board; make administrative and institutional arrangements for procurement; stipulate tendering procedures and provide for purposes connected with these'.

The rules in the public procurement system covers:

Procurement plan: The Act requires procurement entities to prepare a procurement plan for each fiscal year, and develop quarterly updates for approval by the Tender Committee. Procurement planning is expected to be part of the budget preparation process; this should include a detailed breakdown of goods, works and services required in a schedule of delivery, implementation or completion dates for all products, and an estimation of the value of each package of goods, works and services required and the source of funding.

Qualification of tenderers: Tenderers are expected to possess the necessary technical and professional skills, which include finance, personnel, equipment and physical facilities.

Form of communication: The Act requires all communication between procurement entities and tenderers to be in writing.

Record of procurement proceedings: The Act requires a comprehensive record of each procurement proceeding to be maintained and requirements for disclosure when it is needed. The record should contain or indicate the location and source of documents.

Rejection of tenderers, proposals and quotations: The rejection of individual tenders, recommendations, or quotations are subjected to the grounds stated in the tender documents or the request for proposal or quotation. The following are grounds for rejection; when there is evidence of corruption, fraud, coercion, collusion among tenderers and insufficient funding is available for the Procurement.

Entry into force of the procurement contract awards: Successful tender shall be accepted, and notice should be sent to the tenderers within 30 days.

17 Joseph J Schiele and Clifford P McCue, 'Professional service acquisition in public sector procurement', International Journal of Operations and Production Management 26, no 3 (2006), 300-325. 
Inducement from suppliers, contractors, and consultants: Procurement entity or officials should reject all forms of incentive directly or indirectly in the award of contracts. (Public Procurement Act, Act 663, 2003.) From the above one would expect that irregularities associated with Procurement in Ghana would be the thing of the past as the framers of the Act had envisaged, but that was never to be.

\section{Research approach}

A multiple research approach which includes the review of pertinent literature, and analyses of documents (evaluation of reports and contract files) available at the procurement entities were studied. The literature review helped to position the study within its context. The researchers also purposively targeted the field reports in Ghana, news materials, academic literature, books and research findings.

\section{Results and discussions}

One of the most important and celebrated principles of the public procurement legal regime is the principle of transparency. The principle of transparency serves two main objectives: first is to introduce a system of openness in the public purchasing, so potential discrimination can be eliminated; secondly, transparency in public procurement represents a substantial component for a system of best practices for both the public and private sectors, a system which could introduce operational efficiencies within the relevant markets. Article 40, clause one of the Procurement law says, 'a procurement entity may engage in single source with the approval of the board'. However, most procurements in Ghana are single (sole) sourced. Sourcing is either restricted or unknown. National Competitive Tendering is absent in government contracts. This trend is not good enough since the Public Procurement Law aims at ensuring greater competition in all contracts. It was also observed from contract files that most of the contracts which could have been aggregated to attract competition were split into smaller lots that allowed for the use of Request for Quotations (RFQs). In a study undertaken by the Danquah Institute in 2010, it was revealed that public procurement contracts awarded on either the single source or restrictive tender basis were over GH\$ 12 billion (US\$ 2.96 billion in nominal terms). The study further revealed that an estimated 65 per cent savings could have been made if those procurements were subjected to competitive tendering. Instances where the tendering process had been advertised, the contracts have ended up being given to cronies of heads of the governmental agencies seeking the goods and services to be procured. According to Osei-Tutu et al. (2012), ${ }^{18}$ 'this act is a medium for a politician to enrich themselves because contracts are awarded to friends or cronies who simply inflate the cost of the item(s) to be purchased and later give this back to the political heads as kickbacks'.

18 Ernest Osei-Tutu, Ernest Kissi and Safowaa Osei-Tutu, 'Sole Sourcing Procurement: The Ghanaian Procurement Experience', 2012. 
In a related development on how this tool is used to siphon state resources, one of Ghana's anti-corruption journalist, Manasseh Azure Awuni in pain taken investigations conducted in the year 2017 revealed that the Chief Executive Officer of the Public Procurement Authority has been selling or awarding contracts to a company of which he owns shares.

One of the cardinal regulatory tools in Procurement according to the World Bank is transparency, which has to do with fairness and competition in Procurement to bring to public light mistakes, errors in judgments and corrupt practices that affect the management and administration of the country. However, in most cases, the bidding process has not been transparent. If what Manasseh reported was anything to go by, then one cannot but agree with the World Bank that a significant irregularity bedevilling the procurement process in Ghana is a lack of transparency.

Another form of irregularity in the procurement process in Ghana is the situation where contracts are awarded without the due process being followed. A case in point is the award of contract for the supply of drugs worth over two hundred thousand (GH\$ 200,000) at the Tamale Teaching Hospital without due process. Even though the regulation calls for an advertisement to be carried out in the national dailies, this primary requirement in the award of the said contract for drugs to be procured for the hospital was not followed. ${ }^{19}$ In addition to that, owing to procurement irregularities, the World Bank in 2019 rejected an audit report sent to it by the Government of the day. This rejection of the audit report happened because, the said audit report was not conducted by the Ghana Audit Service (GAS), the body clothed with constitutional powers to carry out Government or state audits. The said report was 'an in-depth review' of all Procurement connected expenditures from the period spanning the life of the administration from January 2017 to 30 June 2019. A private audit firm was engaged to conduct the said report, and the World Bank threw it out because 'it is obvious that there were some systemic challenges with procurement and contracts'. Not only that, but the World Bank was also at a loss why the Government could by-pass a state-recognised institution like the GAS and give such a vital task to a private firm to undertake.

\section{Consequences of the procurement irregularities in Ghana}

To every action, it is said, there is an equal reaction, and the various infractions of the procurement policy come with an equal consequence, something, which goes a long way to affect the governance of the country. To start with, one can say that, irregularities lead to loss of funds to the state. In the year 2017 alone, Ghana lost eight hundred and ninety-two million cedis (GHC 892,000,000.00) due to financial irregularities related to Procurement. ${ }^{20}$ Secondly, the anomalies are fertile ground for the payment of needless judgment debts, something which leads to the state losing revenue and not meeting its

\footnotetext{
19 Report of the Auditor-General on the Public Accounts of Ghana Ministries, Departments and other Agencies (MDAs) for the Year ended 31 December 2013 (Accra: Ghana Audit Service, 2014).

20 Majeed Ali, 'Auditor General’s Report on the Public Accounts of Trinidad and Tobago 2017', 2018.
} 
development agenda. ${ }^{21}$ Again, in the year 2011, the Government paid a judgment debt of four hundred and fifteen million cedis (GH\$ 415,000,000.00) to the African Automobile Company limited because of breaches in the procurement for the supply of vehicles to the state. ${ }^{22}$ Furthermore, the irregularities breed corruption, something that the World Bank (2004) $)^{23}$ and other Bretton Wood institutions espouses to be done away within the governance space of every country of which Ghana is no exception.

\section{Recommendations}

As a way of ensuring that the Ghanaian Government gets the best out of the procurement process as envisaged in the passage of the law, the paper recommends that efforts should be geared towards making the law bite. Those found liable must be dealt with according to the criminal laws of the country. Again, for the rule of law to thrive, the Government must have the political will to prosecute members of their political parties when they break the law.

This, when done would send a strong signal to the average Ghanaian that if members of the same political party with the Government of the day are being prosecuted, they too would not be spared should they fall foul of the law. This principle bolsters the argument for the principle of equality before the law. However, this is not the case. In a report released in 2011 by the USAID affirmed that 'while presidential appointees, such as the Minister of Justice and Attorney General, may have the constitutional mandate to uphold the law, they face political incentives not to prosecute members of their party'.

According to Van Greuning (2005), ${ }^{24}$ 'transparency refers to the principle of creating an environment where information on existing conditions, decisions and actions are made accessible, visible and understandable to all individual participants'.

Transparency is, also one of the goals of Procurement and even a significant ingredient and an element of governance. To eliminate the irregularities associated with the procurement process, the process should be transparent as possible to all who have the money to go through all the bidding procedures, and anyone who meets the laid down bidding criterion be awarded the contract. When this is done, it will help erase the perception of corruption in the award of government contracts as far as the procurement procedure is concerned. Further to that, the single source clause in the Act ought to be looked at again and if need be scrapped. The provision of the single source clause has become one of the primary means by which most of the irregularities are channelled through because competitive bidding is pushed to the back burner and every government procurement is sourced through this means.

21 Ibid.

22 Report of the Auditor-General. The Public Accounts of Ghana (Consolidated Fund) for the year ended 31 December 2012 (Accra: Ghana Audit Service, 2013).

23 The World Bank, Uganda country procurement assessment report. Main findings and recommendations [Washington, D.C.: The World Bank, Report No. 32499, (2)].

24 Hennie Van Greuning, International Financial Reporting Standards: A Practical Guide, $5^{\text {th }}$ Edition (Washington, D.C.: The World Bank, 2005). 
It is a known fact that governance is a continuum, a process where gaps should not be entertained in government business. This is because governments inherit both assets and liabilities. To avoid needless payments of judgment debts as the case is in Ghana because successive governments cancel existing contracts and award new ones, breeds a situation where goods and services already procured are left to rot.

To deal with the canker of procurement irregularity, the paper again recommends that the constitution should be amended to compel successive governments to continue with existing contracts on Procurements initiated by past governments regardless of the circumstances under which those goods and services were procured. However, in a situation where actions of certain people are found to have gone contrary to the rules governing the Procurement of any goods and services for the state, to avoid a repetition of such acts, all personalities found to have acted contrary to the law should be surcharged and made to pay for their actions and punished if need be according to the laws of the state.

Further to that since it has become an open secret that the very Act that sought to regulate the procurement process has become the same channel through which fraud is perpetrated on the state. In order to curtail the practice, the Act, Act 663 should be looked at again and if need be the Entity Tender Committees of all State-Owned Enterprises (SOEs) and Metropolitan Municipal and District Assemblies (MMDAs) be broadened to include members who belong to recognised professional bodies with the needed expertise in Procurement. If this is implemented, every step of the way of the procurement process as prescribed in the law would be followed and implemented by the SOEs and MMDAs, something that would protect government purse.

Added to that, as a way to make infractions on Procurement unattractive, is about time government puts the necessary measures in place and ensures that the recommendations of the Auditor General's reports are taken seriously, and these are implemented to the latter.

Ghana, on the assumption of the $4^{\text {th }}$ Republican governance system has made a name for itself in the area of press freedom with the repeal of the criminal libel law. Based upon this, the citizenry and the media which is considered the $4^{\text {th }}$ estate of the realm could be empowered to play a critical role by closely monitoring activities of the government on procurement and in instances where the procurement laws had been breached, they could expose agencies, people and government officials on procurement irregularities.

\section{Conclusion}

The goal of this paper has been an attempt to look at the consequences of procurement irregularities in Ghana. It is an undeniable fact that in as much as Government and its agencies continue to exist to function there would be the need for the necessary supply of goods and services for the smooth running of government business, which is the goal of Procurement. For all intent and purposes, the procurement Act of Ghana has come to serve a need, and it is the law regulating government expenditure. On the contrary, the same law is what state officials are using to milk the state owing to gaps inherited in it, and this is having dire consequences on the state and its resources. 
Since in any governance space obedience of the law is a sine qua non, those found guilty and found to have acted irregularly to the law should be punished to serve as a deterrent to others. The country must consciously find means to protect anti-corruption investigators and practitioners. According to the Ghana Integrity Initiative (GII), the local chapter of Transparency International, the murder of one Ahmed Hussein-Suale, a courageous investigative journalist is a 'dangerous twist to the fight against corruption in Ghana'.

\section{References}

Adjei-Bamfo, Peter, 'Mainstreaming Sustainable Public Procurement in Ghana’s Public Sector: The Role of E-Government’, 2017. Online: http://ugspace.ug.edu.gh/bitstream/ handle/123456789/23518/Mainstreaming\%20Sustainable\%20Public\%20Procurement\%20 in\%20Ghana\%E2\%80\%99s\%20Public\%20Sector\%20the\%20Role\%20of\%20

E-Government.pdf?sequence=1\&isAllowed $=\mathrm{y}$

Adu Sarfo, Patrick, Assessing the Effects of the Procurement Act (663) on Public Financial Management in Ashanti Region. Unpublished thesis submitted to the School of Graduate Studies, Kwame Nkrumah University of Science and Technology, Ghana, 2011.

Adu Sarfo, Patrick and Richard Baah-Mintah, 'Assessing the Effect of the Procurement Act (663) on the Public Financial Management in Ashanti Region'. American Journal of Rural Development 1, no 4 (2013), 91-98. Online: https://doi.org/10.12691/ajrd-1-4-5

Ali, Majeed, 'Auditor General's Report on the Public Accounts of Trinidad and Tobago 2017’, 2018. Online: http://138.128.179.50/sites/default/files/Auditor\%20Generals\%20 Report\%20on\%20the\%20Public\%20Accounts\%202017.pdf

Ameyaw, Collins, Sarfo Mensah and Ernest Osei-Tutu, 'Public Procurement in Ghana: The Implementation Challenges to the Public Procurement Law 2003 (Act 663)'. International Journal of Construction Supply Chain Management 2, no 2 (2012), 55-65. Online: https:// doi.org/10.14424/ijcscm201012-55-65

Brammer, Stephen and Helen Walker, 'Sustainable Procurement in the public sector: an international comparative study'. International Journal of Operations \& Production Management 31, no 4 (2011), 452-476. Online: https://doi. org/10.1108/01443571111119551

Hui, Wee Shu, Radiah Othman, Normah Hj Omar, Rashidah Abdul Rahman and Nurul Husna Haron, 'Procurement issues in Malaysia'. International Journal of Public Sector Management 24, no 6 (2011), 567-593. Online: https://doi. org/10.1108/09513551111163666

Lysons, Kenneth and Brian Farrington, Procurement and Supply Chain Management. Edinburgh Gate: Pearson Education Limited, 2012.

Neupane, Arjun, Jeffrey Soar and Kishor Vaidya, 'An Empirical Evaluation of the Potential of Public E-Procurement to Reduce Corruption'. Australasian Journal of Information Systems 18, no 2 (2014). Online: https://doi.org/10.3127/ajis.v18i2.780

Nichols, Philip M, 'Regulating Transnational Bribery in Times of Globalisation and Fragmentation'. The Yale Journal of International Law 24, no 1 (1999), 257-304. 
Ofori-Mensah, Michael and Lucas Rutherford, 'Effective Parliamentary Oversight: Mission Impossible?’ Governance Newsletter 17, no 3 (2011), 1-9.

Osei-Tutu, Ernest, Ernest Kissi and Safowaa Osei-Tutu, 'Sole Sourcing Procurement: The Ghanaian Procurement Experience’, 2012. Online: www.iaa.ac.tz/downloads/tutu.pdf

Report of the Auditor-General. The Public Accounts of Ghana (Consolidated Fund) for the year ended 31 December 2012. Accra: Ghana Audit Service, 2013.

Report of the Auditor-General on the Public Accounts of Ghana Ministries, Departments and other Agencies (MDAs) for the Year ended 31 December 2013. Accra: Ghana Audit Service, 2014.

Schiele, Joseph J and Clifford P McCue, 'Professional service acquisition in public sector procurement'. International Journal of Operations and Production Management 26, no 3 (2006), 300-325. Online: https://doi.org/10.1108/01443570610646210

Tweneboah Senzu, Emmanuel and Huruna Ndebugri, 'Evaluating the Effectiveness of the Procurement Acts in Public Financial Administration; The Case Study in Ghana', 2017. Online: https://mpra.ub.uni-muenchen.de/78936/1/MPRA_paper_78936.pdf

Tabish, Syed Zafar Shahid and K N Jha, 'Lesson learned from irregularities committed in public procurement’, 2011. Online: www.ippa.org/IPPC4/ Proceedings/18TransparencyAccountabilityinProcurement/Paper18-4.pdf.

Transparency International, 'Corruption Perceptions Index 2019: Overview of Corruption and Anti-Corruption in Ghana', 2019. Online: www.transparency.org/country/GHA

Van Greuning, Hennie, International Financial Reporting Standards: A Practical Guide, $5^{\text {th }}$ Edition. Washington, D.C.: The World Bank, 2005.

The World Bank, Public Procurement Act of Ghana - Country procurement assessment Report. Washington, D.C.: The World Bank, Report No. 29055, 2003. Online: http://documents. worldbank.org/curated/en/2003/06/3582686/ghana-country-procurement-assessmentreport-vol-4-5-annex-8-public-procurement-act

The World Bank, Uganda country procurement assessment report. Main findings and recommendations.

Washington, D.C.: The World Bank, Report No. 32499, (2), 2004. Online: http:// documents.worldbank.org/curated/en/2004/06/5841742/uganda-country-procurementassessmentreport-cpar-vol-2-3-main-findings-recommendations 